\title{
The clinical, molecular, and pathological characterisation of a family with two cases of lethal perinatal type 2 Gaucher disease
}

National Institute of Mental Health, NIH, Bethesda, MD, USA E Sidransky N Tayebi

B K Stubblefield

W Eliason

A Klineburgess

Department of Pathology, Geneva University Hospital, Geneva, Switzerland G-P Pizzolato

J N Cox

J Porta

Division of Medical Genetics, Geneva University Hospital,

Geneva, Switzerland

A Bottani

C D DeLozier-Blanchet

Correspondence to:

Dr Sidransky, Clinical

Neuroscience Branch,

National Institute of Mental

Health, Building 49, Room

B1EE16, 49 Convent Drive

MSC 4405, Bethesda,

Received 19 April 1995

Revised version accepted

for publication

10 October 1995

Ellen Sidransky, Nahid Tayebi, Barbara K Stubblefield, William Eliason, Angelina Klineburgess, Gian-Paolo Pizzolato, Jeremiah N Cox, Josiane Porta, Armand Bottani, Celia D DeLozier-Blanchet

\begin{abstract}
It has recently been emphasised that a subset of patients with type 2 Gaucher disease die in the neonatal period. This report describes an Afghani family with two conceptuses having severe, prenatally detected Gaucher disease. Mutational analysis showed that the family carried a known complex allele which included mutations at amino acids L444P, A456P, and V460V. Although glucocerebrosidase RNA was present, an affected fetus had virtually no glucocerebrosidase cross reactive material on western analyses. The severe clinical course and pathology observed in these patients resemble that of the null allele Gaucher mouse, and suggest that the absence of glucocerebrosidase activity results in early death.

( $f$ Med Genet 1996;33:132-136)
\end{abstract}

Key words: Gaucher disease; hydrops fetalis; glucocerebrosidase.

Until recently type 2 (acute neuronopathic) Gaucher disease was considered stereotypic in presentation, with neurological deterioration and death by the age of 2 to 3 years. ${ }^{1}$ However, the generation of a null allele, knock-out Gaucher mouse $\mathrm{e}^{23}$ led to increased recognition of type 2 patients with a much more aggressive phenotype, who die as neonates. Although 22 neonates with type 2 Gaucher disease have been reported to our knowledge, including some who presented with hydrops fetalis or congenital ichthyosis, ${ }^{1245}$ there has not been comprehensive analysis of glucocerebrosidase mutations, mRNA, and protein in these patients. In this report we describe the molecular characterisation of a family in which two conceptuses had severe, prenatally detected Gaucher disease.

\section{Case reports}

Although consanguinity cannot be proven, the proband's parents both come from the same small, isolated, and inbred Afghani population. They had one healthy son. The second pregnancy (case 1) was complicated by hydramnios developing between 27 and 30 weeks of pregnancy. Prenatal ultrasound detected severe hydrops fetalis with bilateral hydrothorax and fetal hypokinesia with multiple joint con- tractures. Since fetal blood sampling indicated thrombocytopenia and abnormal liver enzymes, labour was induced at 33 weeks' gestation. A $1970 \mathrm{~g}$ male child (fig 1) measuring $40 \mathrm{~cm}$ in length was delivered by caesarean section. He exhibited joint contractures, hepatosplenomegaly, pulmonary hypoplasia, muscular atrophy, and dysmorphic features that included a flattened nose with small nares and malformed ears. The skin appeared tight and shiny, especially over the face, neck, ears, thorax, and extremities. The infant died in the first hour of life. The diagnosis of type 2 Gaucher disease was based on the presence of Gaucher cells in many organs from necropsy material. The parents were subsequently confirmed by enzyme analysis to be heterozygotes for Gaucher disease (mother had $62.1 \%$ and father had $66 \cdot 7 \%$ of control glucocerebrosidase activity). During a third pregnancy (case 2), the prenatal diagnosis of Gaucher disease was made by enzyme assay on cultured amniocytes obtained at week 15 . Neither hydrops nor joint contractures was found in the $640 \mathrm{~g}, 30 \mathrm{~cm}$ male fetus which was aborted at 23 weeks' gestation.

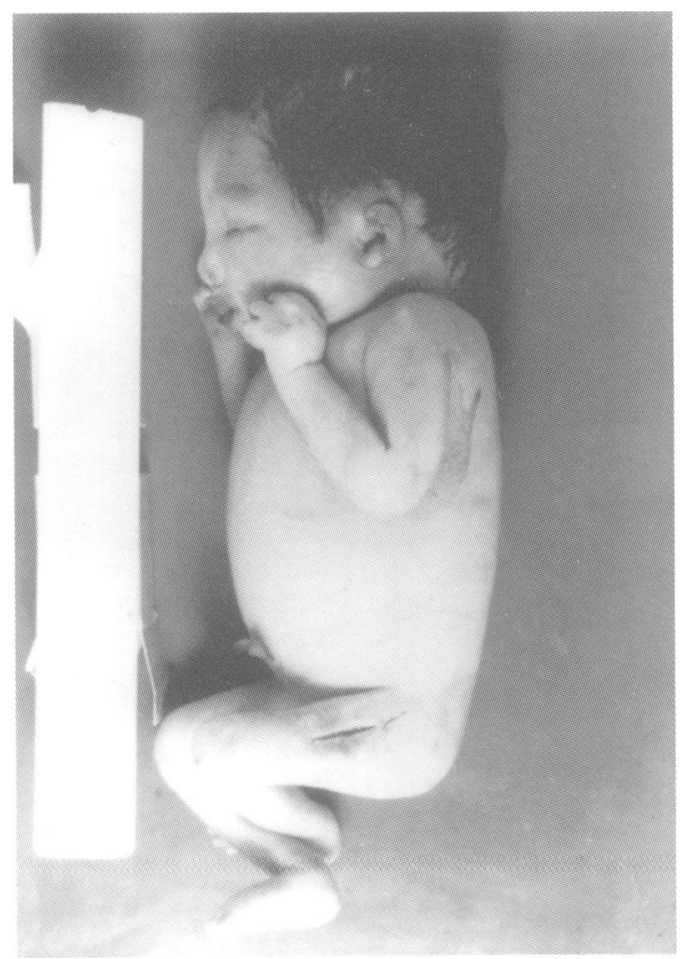

Figure 1 Postmortem photograph of case 1. 
Materials and methods

PATIENT SAMPLES

Pathological specimens were obtained at necropsy from cases 1 and 2 . Amniocytes were obtained from case 2 . Fibroblast lines were derived, with informed consent, from additional patients with type 1 , type 2 , and type 3 Gaucher disease.

\section{MOUSE SAMPLES}

Fresh tissues obtained at necropsy from neonatal type 2 Gaucher mice were immediately frozen in liquid nitrogen.

\section{DNA PREPARATION AND SOUTHERN BLOT} HYBRIDISATION

Genomic DNA was prepared from cultured cell lines from patients and controls as previously described. ${ }^{6}$ Human genomic DNA was digested with $B a m \mathrm{HI}$, electrophoresed on a $1 \%$ agarose gel, transferred to supported nitrocellulose membranes (Schleicher \& Schuell, Keene NH), ultraviolet light cross linked, and then hybridised to a glucocerebrosidase cDNA probe as previously described. ${ }^{7}$ Genomic DNA was also digested with SstII and electrophoresed on a $0.6 \%$ I.D.NA ${ }^{\mathrm{TM}}$ agarose gel (FMC Rockland ME), transferred, and hybridised as described above.

RNA PREPARATION AND NORTHERN BLOT HYBRIDISATION

Total RNA was isolated from frozen cell pellets from case 2 and controls using $\mathrm{RNAzol}^{\mathrm{TM}} \mathrm{B}$ (Biotecx Houston, TX). Approximately $17 \mu \mathrm{g}$ of total RNA from each sample was electrophoresed on a $1 \%$ agarose formaldehyde gel, transferred to a supported nitrocellulose membrane, and ultraviolet light cross linked. The membrane was prehybridised using $33 \mu \mathrm{l} / \mathrm{cm}^{2}$ blot of Quik hybridisation solution (Stratagene, LaJolla, CA) at $68^{\circ} \mathrm{C}$ for 20 minutes, and then hybridised at $68^{\circ} \mathrm{C}$ for one hour using a ${ }^{32} \mathrm{P}$ dCTP random labelled full length glucocerebrosidase cDNA probe. ${ }^{7}$ The blot was washed twice in a $2 \times \mathrm{SSC} / 0 \cdot 1 \%$ (W/V) SDS at room temperature for 15 minutes and once with $0.1 \times \mathrm{SSC} / 0 \cdot 1 \%(\mathrm{~W} / \mathrm{V}) \mathrm{SDS}$ at $60^{\circ} \mathrm{C}$ for 30 minutes. The membrane was exposed to Kodak XAR film with an intensifying screen at $-80^{\circ} \mathrm{C}$ overnight.

\section{MUTATION ANALYSIS}

Screening for the N370S, L444P, R463C, and 84insG mutations was performed as previously described. ${ }^{8}$ A $1290 \mathrm{bp}$ genomic glucocerebrosidase segment, spanning exons 9 to 11 , was selectively amplified using oligonucleotide primers that did not amplify the pseudogene region (forward primer 5'-AACATGATTCCCTATCTTC-3 from intron 8, reverse primer 5'ACCACCTAGAGGGGAAAGTG$3^{\prime}$ from untranslated exon 11). ${ }^{8}$ This amplified DNA fragment was isolated with GeneClean II (Bio 101 LaJolla, CA) and cycle sequencing was performed according to the Taq di deoxy ${ }^{\mathrm{TM}}$ terminator kit (Applied Biosystems, Porter City, IA). The PCR product was purified using an AQUA Select-D-50 column ( $5^{\prime}$ Prime, $3^{\prime}$ Prime, Boulder, CO), vacuum dried, resuspended in loading buffer, denatured at $90^{\circ} \mathrm{C}$, and loaded on a $4.75 \%$ acrylamide, $8.3 \mathrm{~mol} / \mathrm{l}$ urea and $1 \times \mathrm{TBE}$ gel. Results were analysed using the 373 DNA Sequencing Analysis software package (Applied Biosystem, Porter City, IA).

Forward oligonucleotide primers for sequencing were 59F 5'-CACAGGGCTGACCTACCCA-3' (located in intron 8); 142F 5'-GCAGGAGTTATGGGGTGGGTC-3' (located in intron 9); 878F 5'-GTGGGCTGAAGACAGCGTTGG-3' (located in intron 10).

PROTEIN STUDIES

Cell extracts were prepared from frozen human cell pellets and from mouse tissue or fibroblasts as previously described. ${ }^{3}$ Glucocerebrosidase activity was measured using 4-methylumbelliferyl- $\beta$-D-glucopyranoside as substrate. ${ }^{9}$ Nine micrograms of protein from each sample were electrophoresed on denaturing $12 \%$ polyacrylamide gels, and the separated proteins were transferred to Immobilon $P$ membranes. The membranes were incubated
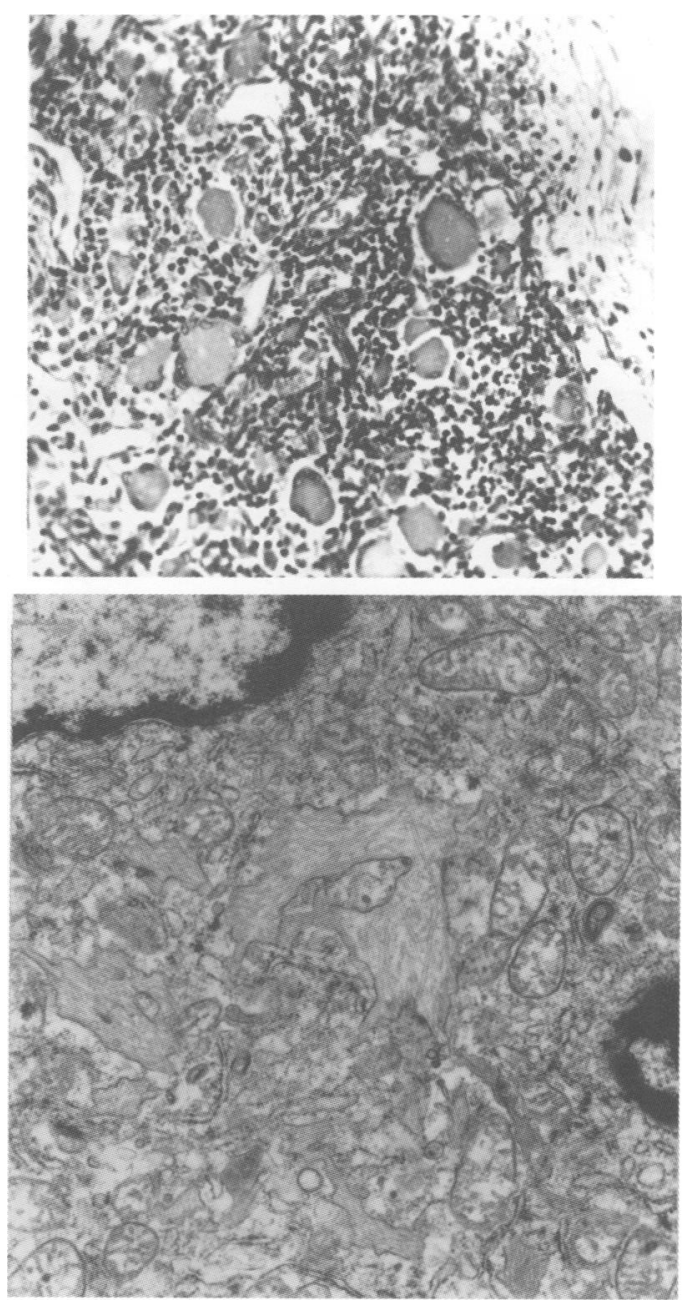

Figure 2 (Top) Histological appearance of a lymph node from case 1, showing Gaucher cells ( $H$ and $E, \times 65$ ). (Bottom) EM picture of a Gaucher cell from a lymph node $(\times 15000)$. 


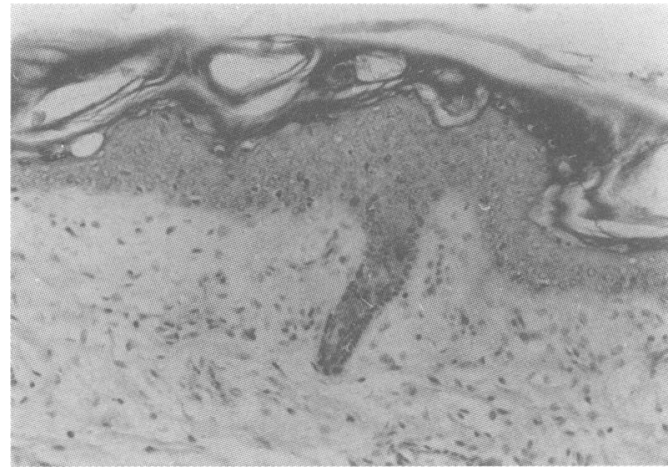

Figure 3 Skin histology from case 1 ( $H$ and $E, \times 160)$.

with rabbit polyclonal antibodies to either mouse or human glucocerebrosidase ${ }^{10}$ and visualised using an ECL chemiluminescence kit (Amersham, Little Chalfont, England).

\section{Results}

\section{PATHOLOGY}

Necropsy of both cases 1 and 2 indicated hepatosplenomegaly and thymic hypoplasia. Gaucher cells (fig 2) were found in the lymph nodes, thymus, spleen, liver, lungs, adrenals, bone marrow, and the central nervous system in both cases but they were less prominent in case 2. The skin histology (case 1) showed an epidermis of normal thickness with a keratinised lamellar layer (fig 3). Examination of the cerebellum and of the spinal cord showed extensive loss of Purkinje cells and lower motor neurones, respectively (fig 4 ). In the central nervous system, numerous PAS positive macrophages were observed, isolated and in groups,

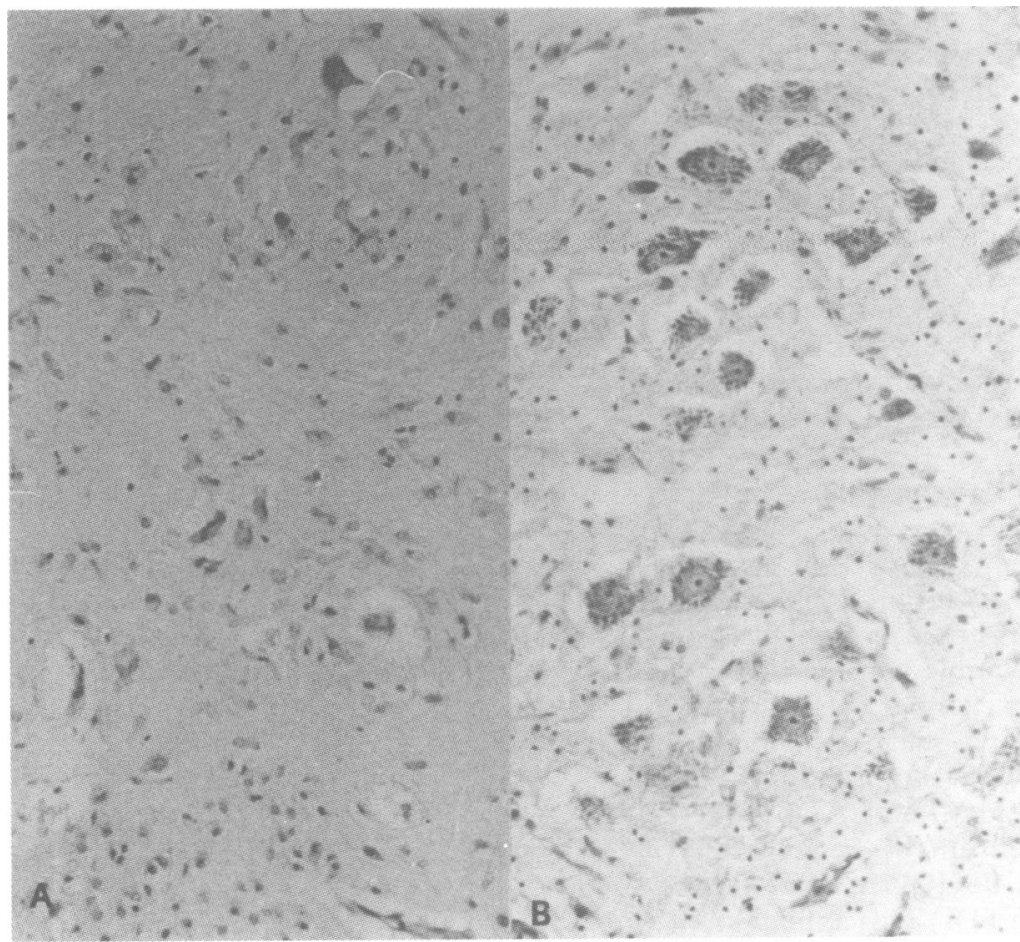

Figure 4 Histological appearance of spinal cord (lumbar enlargement) from $(A)$ case 1 , showing loss of motor neurones, (B) age matched control showing normal motor neurones (Nissl stain, $\times 160$ ). most prominently in the basal ganglia, pons, medulla, oblongata, and the motor neurones of the spinal cord. The involvement of the cerebral cortex was less extensive in case 2 (23 weeks' gestation) than in case 1 (33 weeks' gestation).

\section{SOUTHERN ANALYSES}

Southern analyses were performed on $\mathrm{BamHI}$ digested DNA from case 1, other Gaucher patients, and control samples. All samples showed identical DNA fragment patterns, having the characteristic five bands originating from both the glucocerebrosidase gene and the pseudogene. Southern analyses were also performed on SstII digested DNA from case 2 and a patient with a glucocerebrosidase fusion gene allele. ${ }^{11}$ The expected $48 \mathrm{~kb}$ band was observed in DNA from case 2 . The smaller approximately $28 \mathrm{~kb}$ band characteristic of a fusion gene was not observed.

\section{MUTATION ANALYSIS}

Mutation analysis was performed on DNA from cultured amniocytes from case 2 . A mutation resulting in the substitution of a proline for leucine at amino acid position 444 was detected by a NciI digest of a PCR amplified region of the glucocerebrosidase gene. ${ }^{8}$ There was no normal sequence at this site. Therefore, the fetus was either homoallelic for this mutation or had only one copy of this portion of the glucocerebrosidase locus owing to a deletion in one allele. DNA analyses on the parents were not possible as they had returned to Afghanistan. Nevertheless, since the parents were from the same inbred and isolated ethnic group, it is likely that the fetus was homoallelic for this mutation.

Sequencing of a 1290 base pair PCR product spanning exons 9 to 11 amplified from this fetus confirmed that the L444P mutation was part of a complex allele resulting from a crossover event with the pseudogene. No other mutations were detected on either allele in this region. This complex allele, ${ }^{12-14}$ sometimes referred to as $\operatorname{RecNciI},{ }^{13}$ includes two additional mutations at amino acid positions A456P and V460V. These changes are normally found in the pseudogene sequence.

\section{NORTHERN ANALYSIS}

Northern analyses were performed with total RNA isolated from cell lines from case 2 and from controls. Using glucocerebrosidase cDNA as a probe, the expected $2.6 \mathrm{~kb}$ transcript $\mathrm{t}^{1516}$ was present. Using actin as a standard, the amount of RNA from case 2 was not significantly less than that obtained from the control or other patients.

\section{ENZYME ACTIVITY}

No glucocerebrosidase activity was observed in extracts of amniocytes from case 2 . Similarly, there was no detectable glucocerebrosidase activity in tissue extracts from type 2 Gaucher 
$\mathrm{kDa}$

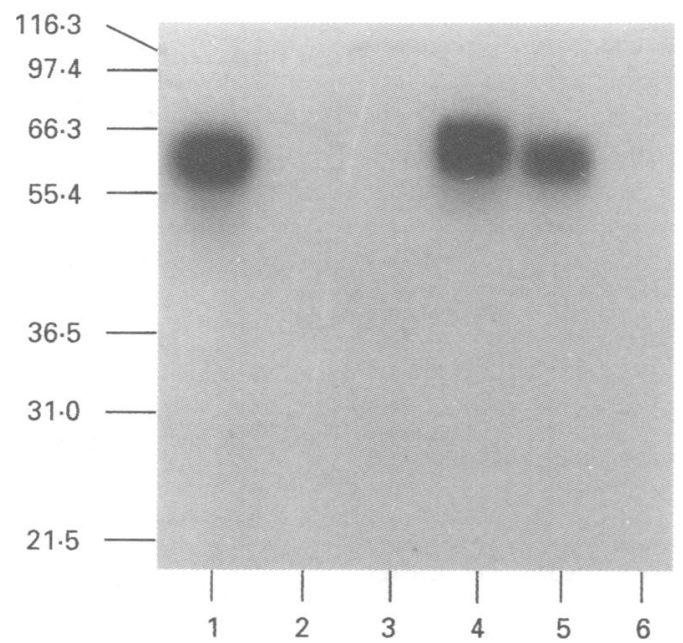

Figure 5 Western blot analysis of glucocerebrosidase protein extracts. Lane 1 normal murine fibroblasts, lane 2 cell line generated from the null allele Gaucher mouse, lane 3 blank, lane 4 normal human fibroblasts, lane 5 fibroblasts from a type 1 Gaucher patient, lane 6 amniocytes from case 2 . Lanes 1 and 2 were incubated with antibody to murine glucocerebrosidase. Lanes 4-6 were incubated with antibody to human glucocerebrosidase.

mice. In contrast, most type 1 and type 3, as well as many longer surviving type 2 Gaucher patients show residual enzyme activity. ${ }^{1718}$

\section{WESTERN ANALYSIS}

Western analyses were performed on extracts from cell lines from case 2, a type 1 Gaucher patient, and a normal subject, as well as from cell lines generated from type 2 Gaucher mice and normal murine fibroblasts. No glucocerebrosidase cross reactive material was detected in extracts from case 2 or the type 2 Gaucher mice (fig 5).

\section{Discussion}

A surprising recent discovery in Gaucher disease has been the recognition of a subset of type 2 patients with pre- or perinatal onset of disease. In this report we have identified the DNA mutations in a family with 23 and 33 week fetuses having clinical, pathological, molecular, and biochemical features resembling those described in type 2 Gaucher mice.

The mutant allele in these fetuses, containing the L444P, A456P, and V460V changes, has been described primarily in the heterozygous state. ${ }^{12-14}$ All three of the observed mutations may result from an unequal homologous recombination, a fusion gene, or gene conversion. ${ }^{11-1419}$ We have found only one other description of a fetus presumably homoallelic for this complex of point mutations, a prenatal lethal, with parents of Macedonian/Ashkenazi Jewish ancestry. ${ }^{5}$ Although that case was described as homozygous for a fusion gene which was suggested to account for some or all of the mutations in neonates, ${ }^{5}$ the authors used the terms "fusion gene" and "complex allele" interchangeably and provided no Southern blot or other evidence to show the actual presence of a fusion allele. Using the restriction endonuclease SstII, which cleaves at one site upstream from the functional gene and at a second site downstream from the pseudogene, ${ }^{11}$ we have shown by Southern analysis of DNA from the present family that a fusion gene was not present. While the family history makes it unlikely, it is still possible that there may be a deletion of the glucocerebrosidase gene in the second allele that is not detectable on our Southern blots.

The close proximity of the human glucocerebrosidase pseudogene $16 \mathrm{~kb}$ downstream from the functional gene is a potential source for the generation of mutant Gaucher alleles. The patients described here appear to have suffered the result of a crossover event occurring in intron 9, an apparently critical region of the glucocerebrosidase gene, resulting in mutations at amino acid positions L444P, L456P, and V460V. In the type 2 Gaucher mouse a severe phenotype was experimentally generated by replacing intron 9 and portions of exons 9 and 10 with a neomycin cassette. ${ }^{3}$ It is possible that the recombination event in the cases described in this report disrupts a region with a regulatory, enhancer, or RNA stability element or another contiguous gene. ${ }^{2021}$

While homozygosity for this mutant allele in the two known cases appears to be predictive of very severe Gaucher disease, none of seven other neonates with this phenotype studied by our group or others share this genotype. ${ }^{42223}$ We postulate that at least one other unknown mutation or rearrangement associated with such severe disease must exist, and thus are continuing the search for mutations in the regions flanking the glucocerebrosidase gene.

Although a glucocerebrosidase transcript was present in cells from case 2 , no significant glucocerebrosidase cross reactive material was detected on western blot. This suggests either that the protein was not produced, or that it was very unstable. Reports regarding stability of the protein from the complex allele RecNciI are conflicting. ${ }^{1213}$ One group has suggested the production of a stable protein with very low enzymatic activity. ${ }^{13}$ Another possibility, that of reduced amounts of a very unstable protein, appears to be more likely. ${ }^{12}$

Gaucher disease, particularly this severe lethal subgroup, should be considered in fetuses and neonates with hydrops fetalis, ichthyosis, or joint contractures. Both hydrops and arthrogryposis were present in the fetus diagnosed at 33 weeks' gestation, whereas they apparently had not yet developed in the fetus aborted at 23 weeks. The histological abnormality of the skin observed in case 1 substantiates that the analysis of epidermis can be particularly valuable in the diagnosis of neonatal Gaucher disease. ${ }^{24}$

In both the fetuses described here and the null allele Gaucher mouse, the absence of enzyme was incompatible with long survival. Neuropathological studies of both sibs showed findings very similar to those in the null allele mouse, in that both had an apparent rostalcaudal progression of lesions with lipid ac- 
cumulation varying within different brain regions. ${ }^{25}$ Further pathological and biochemical studies of the severely affected type 2 Gaucher mice may offer a unique opportunity to transfer insights from the murine model towards a better understanding of the pathogenesis of the disease, perhaps leading to development of new treatments for type 2 Gaucher disease.

We thank Professor N Herschkowitz for the clinical biochemica analysis as well as Drs P Extermann, M Bader, C Pag, and Szalay for patient care. The fibroblast line from the patient with a fusion gene was kindly provided by Dr E Beutler. The murine cell lines were kindly provided by Dr C McKinney. Helpful discussions with Drs E Ginns and B Martin are greatly appreciated. The experienced technical assistance of $\mathrm{P}$ Williams is gratefully acknowledged. The authors also thank $\mathrm{K}$ Kuhns is gratefully acknowledged. The authors also

1 Fredrickson DS, Sloan HR. Gaucher disease. In: Stanbury JB, Wyngaarden JB, Frederickson DS, eds. The metabolic basis of inherited disease. New York: McGraw-Hill, 1978: 731-59.

2 Sidransky E, Sherer D, Ginns EI. Gaucher disease in the neonate: a distinct Gaucher phenotype is analogous to neonate: a distinct Gaucher phenotype is analogous to a mouse model created by targeted disruption of

3 Tybulewicz V, Tremblay ML, LaMarca ME, et al. Targeted disruption of the mouse glucocerebrosidase gene: development of an animal model of Gaucher disease. Nature 1992;357:407-10.

4 Sherer DM, Metlay L, Sinkin RA, Mongeon C, Lee RE, Woods JR. Congenital ichthyosis with restrictive dermopathy and Gaucher's disease: a new syndrome with associated prenatal diagnostic and pathology findings. Obstet Gynecol 1993;81:843-4.

5 Strasberg PM, Skomorowski MA, Warren IB, Hilson WL Callahan JW, Clarke JTR. Homozygous presence of the crossover (fusion gene) mutation identified in a type II crossover (fusion gene) mutation identified in a type knock-out mouse model? Biochem Med Metabol Biol 1994; knock-out

6 Maniatis T, Fritsch EF, Sambrook J. Molecular cloning: a laboratory manual. New York: Cold Spring Harbor Laboratory Press, 1982

7 Tsuji S, Choudary PV, Martin BM, Mayor JA, Barranger JA, Ginns EI. A mutation in the human glucocerebrosidas gene in neuronopathic Gaucher's disease. $N \mathrm{Engl} \mathrm{f} \mathrm{Med}$ 1987;316:570-5.

8 Sidransky E, Bottler A, Stubblefield B, Ginns EI. DNA mutational analysis of type 1 and type 3 Gaucher patients: how well do mutations predict phenotype? Hum Mutat 1994;357:407-10.
9 Beutler E, Kuhl WL. Detection of the defect of Gaucher's disease and its carrier state in peripheral blood leukocytes. Lancet 1970;i:612-13.

10 Ginns EI, Brady RO, Pirruccello S, et al. Mutations of glucocerebrosidase: discrimination of neurologic and nonneurologic phenotypes of Gaucher disease. Proc Natl Acad Sci USA 1982;79:5607-10.

11 Zimran A, Sorge J, Gross E, Kubitz M, West C, Beutler E A glucocerebrosidase fusion gene in Gaucher disease. $\mathcal{F}$ Clin Invest 1990;85:219-22.

12 Ohashi T, Hong CM, Weiler S, et al. Characterization of human glucocerebrosidase from different mutant alleles. f Biol Chem 1991;266:3661-7.

13 Horowitz M, Zimran A. Mutations causing Gaucher disease. Hum Mutat 1994;3:1-11.

14 Latham T, Grabowski GA, Theophilus BDM, Smith FI. Complex alleles of the acid $\beta$-glucocerebrosidase gene in Gaucher disease. Am F Hum Genet 1990;47:79-86.

15 Reiner O, Horowitz $M$. Differential expression of the human glucocerebrosidase gene. Gene 1988;73:469-78.

16 Graves PN, Grabowski GA, Ludman MD, Palese P, Smith FI. Human acid beta-glucosidase: northern blot and $\mathrm{S} 1$ nuclease analysis of mRNA from HeLa cells and normal and Gaucher disease fibroblasts. Am f Hum Genet 1986; 39:763-74.

17 Wenger DA, Olson GC. Heterogeneity in Gaucher disease. In: Callahan JW, Cowten JA, eds. Lysosomes and lysosomal storage disonders. New York: Raven Press, 1981:157-71.

18 Fabbro D, Desnick RJ, Grabowski GA. Gaucher disease: genetic heterogeneity within and among the subtypes detected by immunoblotting. Am F Hum Genet 1987;40: 15-31.

19 Zimran A, Horowitz M. RecTL: a complex allele of the glucocerebrosidase gene associated with a mild clinical course of Gaucher disease. Am 7 Med Genet 1994;50 74-8.

20 Ginns EI, Winfield S, Sidransky E, Long GC, Bornstein P. Characteristics of a novel gene at the Gaucher disease locus spanning the regions between the glucocerebrosidase pseudogene and thrombospondin. Am 9 Hum Genet 1994; 53:A325

21 Bornstein P, McKinney CE, LaMarca ME, et al. Targeted disruption of a novel gene contiguous to both glucocerebrosidase and thrombospondin 3 results in an embryonic lethal phenotype in the mouse. Proc Natl Acad Sci bSA 1995;92:4547-51.

22 Lewis BD, Nelson PV, Robertson EF, Morris CP. Mutation analysis of 28 Gaucher disease patients: the Australasian experience. Am f Med Genet 1994;49:218-23.

23 Tayebi N, Stubblefield B, Eliason W, Klineburgess A, Ginns EI, Sidransky E. Molecular analysis of severe type 2 Gaucher disease. Pediatr Res 1995;37:153A.

24 Holleran WM, Ginns EI, Menon GK, et al. Epidermal consequences of glucocerebrosidase deficiency. F Clin Invest 1994;93:1756-64.

25 Willemsen R, Tybulewicz V, Sidransky E, et al. A biochemical and ultrastructural evaluation of the type 2 Gaucher mouse. Mol Chem Neuropathol 1995;24:179-92. 